\title{
GEOKIMIA SEBARAN UNSUR LOGAM PADA ENDAPAN LUMPUR SIDOARJO
}

\author{
Oleh \\ Sabtanto Joko Suprapto*, Rudy Gunradi*, dan Yose Rizal Ramli** \\ *Kelompok Program Penelitian Konservasi, **Kelompok Program Penelitian Mineral \\ Pusat Sumber Daya Geologi
}

\begin{abstract}
SARI
Semburan lumpur panas Sidoarjo mulai muncul pada tanggal 29 Mei 2006 di areal persawahan Desa Siring, Kecamatan Porong, Kabupaten Sidoarjo, Provinsi Jawa Timur. Jarak titik semburan sekitar 150 meter arah Barat Daya sumur Banjar Panji I milik PT. Lapindo Brantas yang saat itu sedang dilakukan pemboran vertikal untuk mencapai Formasi Kujung pada kedalaman 10.300 kaki.

Fenomena geologi berupa luapan lumpur panas sangat menarik banyak pihak yang mendorong untuk melakukan bermacam kajian. Analisis berbagai parameter untuk mengungkap fenomena yang ada telah memperkaya khasanah kegeologian di Indonesia.

Suhu luapan lumpur yang tinggi telah menimbulkan asumsi kemungkinan adanya pengaruh larutan hidrotermal yang ikut terbawa ke luar bercampur bersama luapan lumpur. Sebagai akibatnya maka akan terbawa juga unsur-unsur logam yang umum dijumpai pada larutan hidrotermal terutama yaitu $\mathrm{Cu}, \mathrm{Pb}, \mathrm{Zn}, \mathrm{Mn}, \mathrm{Fe}, \mathrm{Cd}$, As, $\mathrm{Sb}, \mathrm{Au}, \mathrm{Ag}, \mathrm{Hg}$, dan $\mathrm{Se}$.
\end{abstract}

\section{ABSTRACT}

The hot mud ejection of Sidoarjo started emerging on 29 May 2006 at a rice field area of Siring Village, Porong Subdistrict, Sidoarjo Regency, East Java Province. Location of this ejection point is around 150 meters southwest of Banjar Panji 1 well of PT. Lapindo Brantas. This phenomenon happened when a vertical drilling was being done to reach Kujung Formation at the depth of 10,300 feet.

This geologic phenomenon in the form of hot mudflow is a very attractive evidence to many sides which encourage for conducting a variety of research works. Analysis of various parameters related to evidence it is intended to reveal the existing natural phenomenon which has enriched geological knowledge in Indonesia.

High temperature of the mudflow has generated assumptions of possible existence of hydrothermal fluid influence which has been mixing with the mudflow on the way up to the surface. As a result, hence it will also bring along metallic elements commonly within hydrothermal fluid especially $\mathrm{Cu}, \mathrm{Pb}, \mathrm{Zn}, \mathrm{Mn}, \mathrm{Fe}, \mathrm{Cd}$; $\mathrm{As}, \mathrm{Sb}, \mathrm{Au}, \mathrm{Ag}, \mathrm{Hg}$, and Se.

\section{PENDAHULUAN}

Lokasi semburan Lumpur Sidoarjo, Terletak di Desa Siring, Kecamatan Porong, Kabupaten Sidoarjo (Gambar 1). Semburan lumpur panas di Sidoarjo merupakan fenomena geologi yang menarik dan menjadi perhatian tidak saja para ahli dari dalam negeri namun juga dari luar negeri. Awal semburan terjadi di sekitar Sumur Banjar Panji 1 (BJP-1), dengan debit $5.000 \mathrm{~m} 3 /$ hari. Lubang semburan terjadi di beberapa tempat, sebelum akhirnya menjadi satu lubang yang dari waktu ke waktu menyemburkan lumpur panas dengan volume yang terus meningkat. Pada bulan MeiAgustus 2006 debit lumpur telah mencapai $126.000 \mathrm{~m} 3 /$ hari (Gambar 2).

Semburan lumpur dari lubang pemboran yang menembus sampai pada kedalaman 10.300 kaki membawa bahan padat dan cair dengan unsur-unsur dan senyawa terlarut di dalamnya. Bahan padat berasal dari batuan penyusun formasi yang ditembus lubang bor, sedangkan bahan cair sangat tergantung kondisi geologi dan hidrogeologi daerah di sekitarnya.

Unsur-unsur dan senyawa terlarut pada fluida yang terbawa keluar bersama semburan lumpur panas akan terdispersi dan mempengaruhi kandungan kimiawi lumpur. Akumulasi dari unsur-unsur tertentu yang terus terbawa dalam fluida, pada kurun waktu yang lama berpotensi menimbulkan perubahan kandungan kimiawi lumpur dan lingkungan yang terlewati.

Pola sebaran unsur dan kecenderungan perubahan kandungan dari waktu ke waktu perlu dicermati sebagai dasar penanganan di antaranya potensi untuk peluang pemanfaatan.

Tingginya suhu lumpur menimbulkan hipotesais kemungkinan adanya sistim geotermal yang ikut berperan pada mekanisme keluarnya material lumpur panas. Sistim geotermal dapat terbentuk oleh pengaruh magmatik menghasilkan larutan hidrotermal yang umumnya mengandung unsur-unsur logam antara lain $\mathrm{Cu}, \mathrm{Pb}, \mathrm{Zn}, \mathrm{Mn}$, $\mathrm{Fe}, \mathrm{Cd}, \mathrm{As}, \mathrm{Sb}, \mathrm{Au}, \mathrm{Ag}, \mathrm{Hg}$, dan Se. 


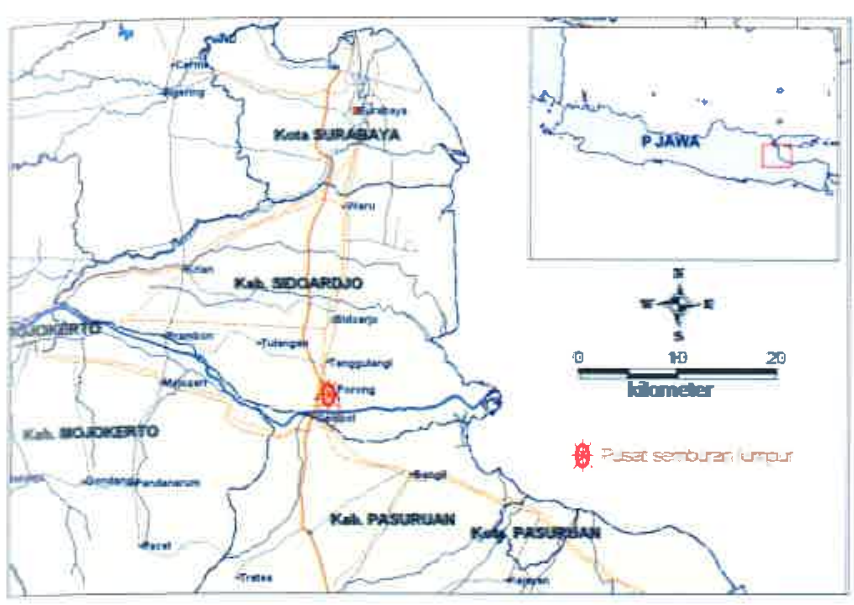

Gambar 1. Peta indek lokasi endapan lumpur

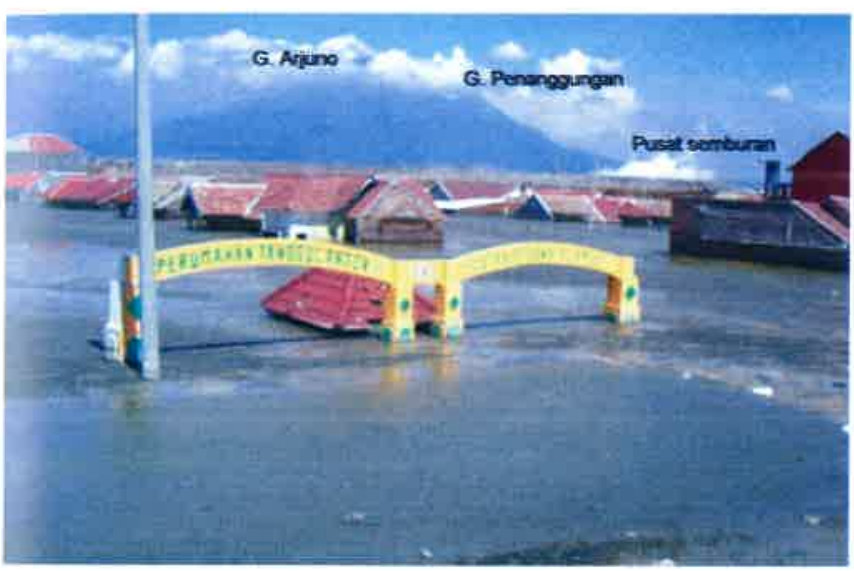

Gambar 2. Endapan lumpur Sidoarjo dengan latar belakang pusat semburan, Gunung Penanggungan dan Gunung Arjuno

\section{GEOLOGI}

Secara fisiografis daerah kegiatan termasuk ke dalam Zona Randublatung yang merupakan zona sempit memanjang sekitar $250 \mathrm{~km}$ dan lebar $10 \mathrm{~km}$ dari Semarang sampai Surabaya.

Secara struktur bawah permukaan Zona Randublatung diindikasikan sebagai triangle zone, sebuah zona segitiga yang diapit zona-zona sesar yang saling berlawanan kemiringan dan arahnya. Di Jawa Tengah dan Jawa Timur, Zona Randublatung merupakan wilayah pertemuan dua buah zone besar yakni Zona Rembang dan Zona Kendeng.

Zona Rembang merupakan daerah paparan dan slope yang dicirikan dengan dominasi sesar naik yang mengarah (vergency) ke selatan. Zona Kendeng merupakan slope dan bathyal dengan dominasi sesar naik ke arah utara. Sehingga di daerah pertemuan tersebut terbentuk sebuah zona sangat sempit, memanjang dan sangat dalam yang disebut Zona Randublatung. Pada Oligo-Miosen zona ini secara isostatik tenggelam untuk mengkompensasi pengangkatan di kedua zona pengapitnya dan menjadi dapur yang baik untuk terakumulasinya hidrokarbon selama ada suplai sedimen yang kaya organik dan diendapkan di dalamnya.

Subsided triangle zone memberikan implikasi terhadap pematangan batuan induk dan adanya sub-thrust structure di bawah zona sesar naik menjadi perangkap yang baik, sedangkan reservoir akan tergantung kepada adanya sedimen berkualitas reservoir dari lingkungan yang lebih dangkal. Batupasir kuarsa Formasi Kerek dan Merawu yang berumur Miosen Tengah dan sedimen debris kuarsaan dari Formasi Ngrayong berumur Miosen Tengah yang diendapkan ke Zona Randublatung dan Kendeng, sumbernya banyak mengandung serpih napalan dan sedimen calcareous lainnya.

Dengan tataan geologi yang demikian menjadikan Zona Randublatung menjadi daerah prospek minyak dan gas dan telah dibuktikan dengan temuan Pertamina di karbonat Formasi Kujung pada zona ini.

Secara stratigrafis pada masa Pleistosen merupakan daerah lingkungan laut, Selat Madura menjorok jauh ke barat hampir sampai Kota Semarang. Sungai-sungai seperti Bengawan Solo dan sungai lainnya bermuara di Selat Madura purba mengendapkan sedimen seperti pasir dan lumpur sehingga terbentuk delta pada pantainya yang selanjutnya berangsur-angsur terjadi pendangkalan. Akibat pendangkalan tersebut lama kelamaan daratan bertambah ke arah pantai Selat Madura dan terbentuklah daratan seperti yang terlihat saat ini. Pada peta geologi regional lembar Surabaya dan Sapulu dan peta geologi regional lembar Malang yang dikeluarkan Pusat Penelitian dan Pengembangan Geologi, disebutkan bahwa batuan penyusun daerah kegiatan adalah endapan aluvial (Santosa dan Suwarti, 1992).

Beberapa kilometer di selatan Porong dominasi endapan gungungapi Kuarter dalam sebaran yang luas, dan endapan dari gunungapi yang sampai saat ini masih aktif (Gambar 3 \& 4).

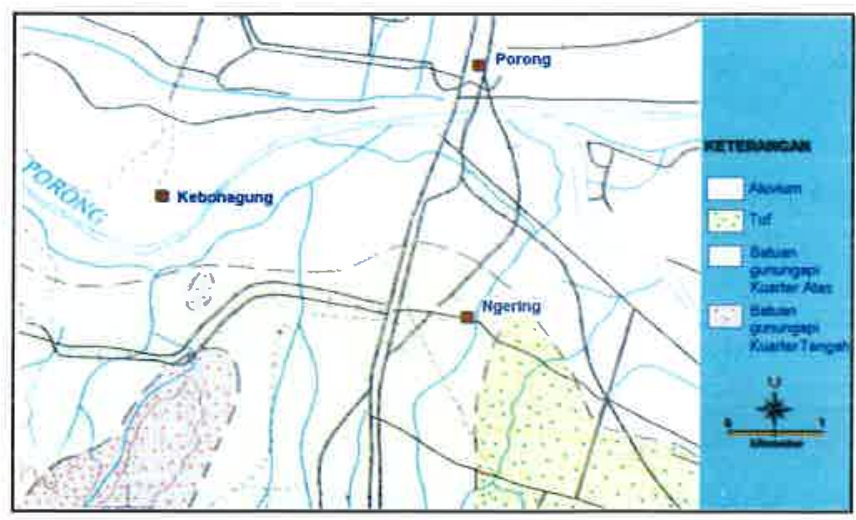

Gambar 3. Peta geologi (Santosa dan Suwarti, 1992) 


\section{HIPOTESIS}

Fenomena luapan lumpur panas Sidoarjo telah memicu banyak pakar untuk membuat telaah dan hipotesis tentang mekanisme keterjadiannya, termasuk aspek di luar geologi perminyakan yang ikut menyertai dalam mekanisme terjadinya lumpur panas. Suhu lumpur yang panas, semula dianggap hanya pengaruh faktor gradien geotermis. Akan tetapi dengan tingginya suhu mendekati $100 \mathrm{oC}$ memberikan alternatif lain di luar aspek gradien geotermis yang ikut mempengaruhi suhu lumpur. Meskipun titik semburan berada pada lingkungan geologi berupa cekungan sedimenter, akan tetapi mengingat Pulau Jawa berada pada busur volkanik, pengaruh magmatik sangat mungkin ikut menyertai mekanisme munculnya lumpur panas. Hal ini didukung dengan adanya batuan gunungapi Kuarter yang terdapat sekitar dua kilometer di selatan pusat semburan, dan dijumpai juga adanya aktivitas gunung api (Gambar 3 \& 4).

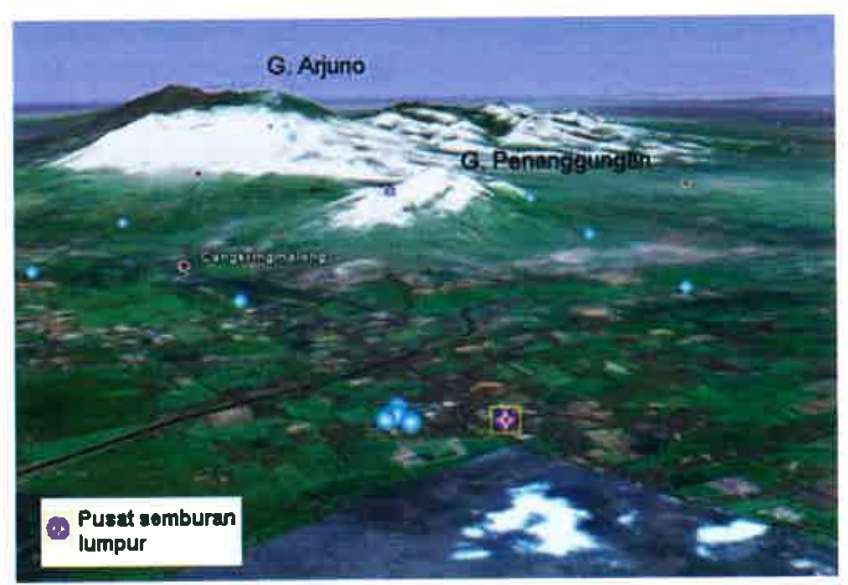

Gambar 4. Lokasi semburan lumpur, latar belakang G. Penanggungan dan G. Arjuno (sumber image dari Google Earth)

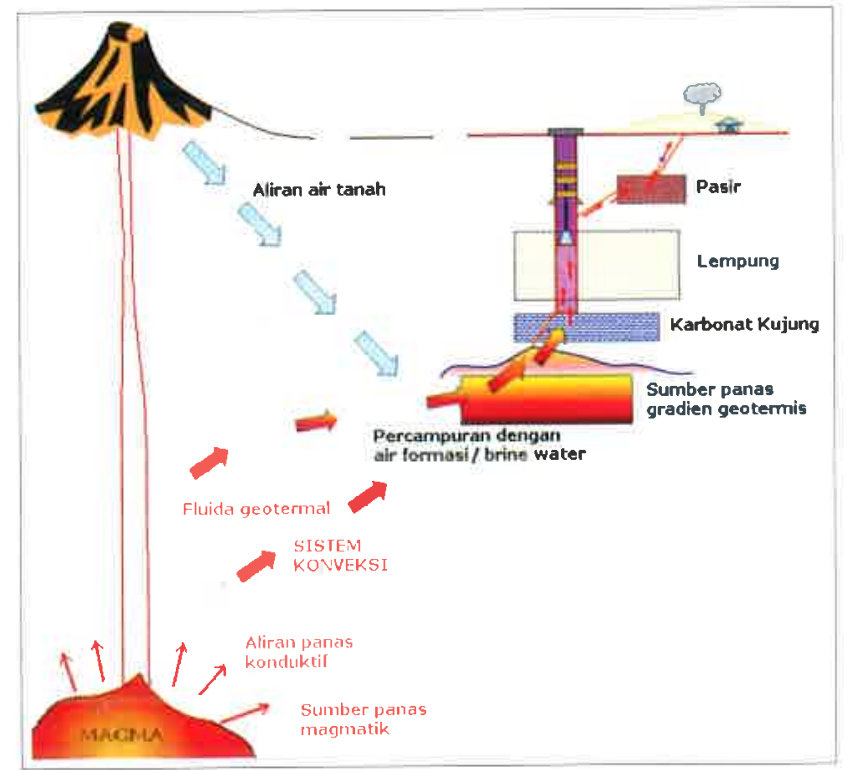

Gambar 5. Sketsa hipotesis pembentukan lumpur panas (modifikasi dari Rovicky, 2007)
Daerah selatan Sidoarjo berupa daerah tinggian tersusun oleh batuan gunungapi, merupakan zona resapan air tanah yang potensial menjadi sumber air dalam satu siklus hidrogeologi yang dapat mempengaruhi juga kondisi hidrogeologi di daerah Porong. Sistem fluida geotermal sebagai efek magmatik pada zona kedalaman tertentu, membentuk konveksi aliran fluida panas (hidrotermal), mempunyai daerah pengaruh potensial dapat menjangkau sampai Formasi Kujung dan ikut mengkontaminasi fluida yang ada pada zona di bawah pusat semburan (Gambar 5).

Fluida geotermal bersifat asam, potensial melarutkan unsur logam, sehingga kandungan unsur pada lumpur akan terpengaruh. Suhu dengan kisaran mendekati $100 \mathrm{oC}$ merupakan zona epitermal yang umumnya merupakan zona dijumpainya $\mathrm{Cu}, \mathrm{Pb}, \mathrm{Zn}, \mathrm{Mn}, \mathrm{Fe}, \mathrm{Cd}, \mathrm{As}, \mathrm{Sb}$, $\mathrm{Au}, \mathrm{Ag}, \mathrm{Hg}$, dan Se (Gambar 6).

Fluida geotermal berasal dari cairan sisa magma, dapat juga dari air tanah yang terkonduksi panas magmatik, atau percampuran keduanya. Karakteristik fluida geotermal tidak selalu konstan, dapat berubah-ubah tergantung aktivitas magmatik itu sendiri serta siklus geohidrologi pada zona di sekitarnya. Hal ini akan mempengaruhi kandungan unsurunsur terlarut di dalam fluidanya.

\section{METODOLOGI}

Penyelidikan geokimia sebaran unsur logam pada endapan lumpur Sidoarjo didasari pada hipotesis akan kemungkinan adanya fluida geotermal yang terbawa bersama semburan lumpur panas. Fluida geotermal atau dikenal dengan hidrotermal pada suhu sekitar $100 \mathrm{oC}$ potensial melarutkan unsur-unsur logam $\mathrm{Cu}, \mathrm{Pb}, \mathrm{Zn}, \mathrm{Mn}, \mathrm{Ag}$, $\mathrm{Fe}, \mathrm{Cd}, \mathrm{As}, \mathrm{Sb}, \mathrm{Au}$, dan $\mathrm{Se}$.

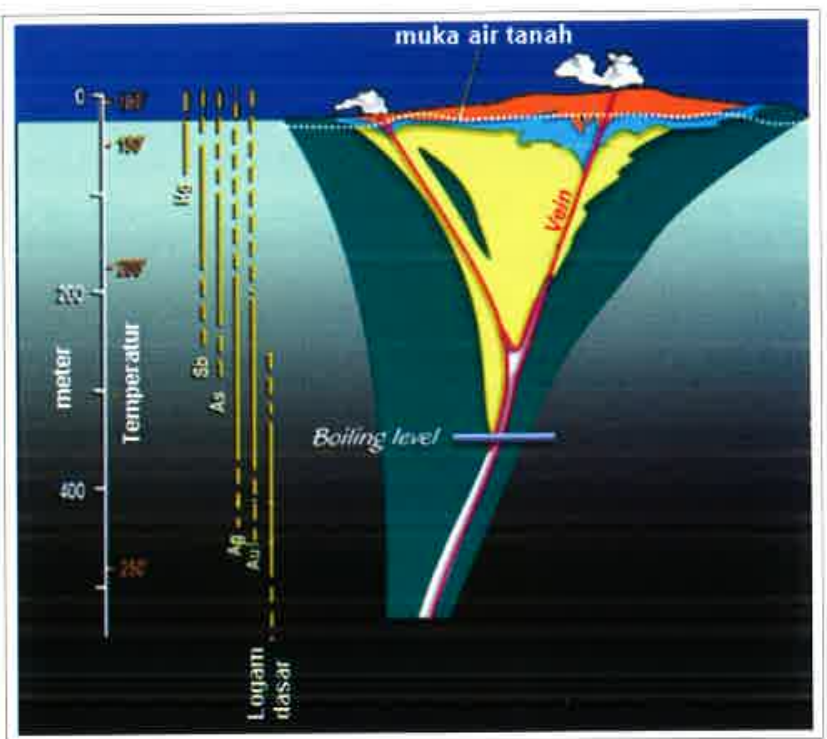

Gambar 6. Model sebaran unsur logam pada zona epitermal (Buchanan, 1981 dalam Panteleyev, 1990) 
Sampel lumpur diambil pada lokasi di sekitar tanggul. Pada setiap lokasi diambil satu conto. Pengambilan lumpur untuk mendapatkan gambaran sebaran unsur secara vertikal sulit dilakukan mengingat kondisi lumpur masih sangat lunak sehingga pada kisaran ketebalan sekitar lima meter hanya terambil satu sampel. Pengambilan sampel lumpur dilakukan di antara tanggal 28 Maret 2007 dan $11 \mathrm{Mei}$ 2007

Sebaran unsur logam disusun berdasarkan hasil analisis kimia conto lumpur dari 86 lokasi, yang jarak antar titik lokasi 200 - 400 meter (Gambar 8). Analisis kimia unsur logam dilakukan di Laboratorium Kimia Pusat Sumber Daya Geologi.

\section{GEOKIMIASEBARAN UNSUR LOGAM}

Hasil pengukuran $\mathrm{pH}$ di lapangan menunjukan lumpur bersifat basa dengan kisaran nilai $\mathrm{pH}$ 8-9. Hasil analisis kimia diperoleh perbandingan antara harga kisaran kandungan logam dalam lumpur dan kandungan rata-rata unsur logam dalam batulempung pada kerak bumi terdapat nilai sedikit lebih tinggi untuk beberapa unsur.

\section{Sebaran Unsur Logam}

Hasil analisis statistik terhadap kandungan unsur diperoleh kandungan rata-rata beberapa unsur umumnya di atas rata-rata kandungan unsur yang umum pada batu lempung. Rata-rata kandungan unsur agak tinggi tersebut terdiri dari $\mathrm{Pb}, \mathrm{Zn}, \mathrm{Mn}, \mathrm{Ag}, \mathrm{Cd}, \mathrm{Sb}, \mathrm{Au}, \mathrm{Se}$ dan $\mathrm{Hg}$ (Tabel 1).

Sebaran unsur Ag mempunyai rata-rata agak tinggi, namun harga tertinggi hanya $2 \mathrm{ppm}$. Pola sebaran unsur (Gambar 9.A) menunjukkan peninggian harga Ag di sekitar pusat semburan.

Kandungan As di bawah harga rata-rata kandungan As umumnya pada batu lempung, namun pola sebaran unsur menunjukkan harga yang relatif meninggi ke arah sekitar pusat semburan (Gambar 9.B). Pola peninggian As di sekitar pusat semburan menunjukkan kemungkinan bahwa terdapat dispersi nilai As yang bersumber dari semburan lumpur.

Rata-rata kadar Au relatif lebih tinggi dibandingkan rata-rata umumnya pada batu lempung. Sebaran Au pada dekat pusat semburan mempunyai nilai rendah. Akan tetapi sedikit ke arah utara pusat semburan terdapat pola peninggian nilai $\mathrm{Au}$ (Gambar 9.C). Pola tersebut kurang memberikan gambaran asal dispersi dari Au. Namun kemungkinan besar peninggian tersebut terdispersi dari dari pusat semburan, hal ini mengingat kuantitas Au secara keseluruhan cukup besar maka apabila sebagai akibat kontaminasi dari lingkungan sekitarnya sangat kecil kemungkinannya. Endapan lumpur di Desa Siring dan
Kedung Bendo yang terendapkan relatif lebih awal mempunyai pola kandungan Au lebih tinggi dibandingkan pola sebaran kandungan Au di dekat pusat semburan (Gambar 9.C) yang merupakan endapan luapan lumpur lebih belakangan, hal ini kemungkinan sebagai akibat fluktuasi kandungan Au pada lumpur yang keluar.

Tabel 1. Ringkasan statistik kandungan unsur logam pada 86 sampel lumpur dan kadar pembanding pada batulempung

(Satuan dalam ppm kecuali Fe : \%, Au \& Hg:ppb)

\begin{tabular}{|c|c|c|c|c|c|}
\hline Unsur & Min & Maks & $\begin{array}{c}\text { Rata } \\
\text { rata }\end{array}$ & $\begin{array}{c}\text { Standar } \\
\text { deviasi }\end{array}$ & $\begin{array}{c}\text { Rata-rata } \\
\text { dalam } \\
\text { batu } \\
\text { lempung }\end{array}$ \\
\hline $\mathrm{Cu}$ & 19 & 47 & 22,49 & 4,508 & 42 \\
\hline $\mathrm{Pb}$ & 37 & 72 & 49,40 & 5,693 & 25 \\
\hline $\mathrm{Zn}$ & 77 & 142 & 96,29 & 11,483 & 100 \\
\hline $\mathrm{Mn}$ & 317 & 1095 & 653,78 & 101,992 & 850 \\
\hline $\mathrm{Ag}$ & 0 & 2 & 0,95 & 0,270 & 0,19 \\
\hline $\mathrm{Fe}$ & 3,12 & 3,98 & 3,55 & 0,38 & 4,7 \\
\hline $\mathrm{Cd}$ & 4 & 8 & 6,01 & 0,888 & 0,3 \\
\hline $\mathrm{As}$ & 1 & 10 & 3,46 & 1,934 & 12 \\
\hline $\mathrm{Sb}$ & 1 & 30 & 4,13 & 4,774 & $1-2$ \\
\hline $\mathrm{Au}$ & 1 & 15 & 5,37 & 4,092 & 4 \\
\hline $\mathrm{Se}$ & 2,6 & 127 & 83,528 & 24,380 & 0,6 \\
\hline $\mathrm{Hg}$ & 0 & 106 & 20.41 & 18,245 & $0,02-0,4$ \\
\hline
\end{tabular}

Sebaran unsur $\mathrm{Cd}$ mempunyai rata-rata relatif tinggi. Nilai tinggi dijumpai juga di sekitar pusat semburan. Meskipun pola sebaran unsur $\mathrm{Cd}$ cenderung kurang teratur namun mendekati pusat semburan mempunyai kecenderungan meninggi.

Kandungan unsur $\mathrm{Cu}$ mempunyai rata-rata rendah. Nilai maksimum meskipun lebih tinggi dibandingkan ratarata pada kandungan lempung, akan tetapi tidak jauh berbeda (Gambar 9.E). Pola sebaran unsur Cu mirip dengan Cd.

Rata-rata kadar Fe relatif rendah. Pola sebaran mirip dengan $\mathrm{Cu}$ dan $\mathrm{Cd}$. Kandungan $\mathrm{Fe}$ meskipun ada imbuhan dari semburan lumpur, akan tetapi mempunyai nilai kisaran harga yang tidak menunjukkan adanya peninggian secara signifikan (Gambar 9.F).

Unsur Hg mempunyai harga rata-rata relatif tinggi dan mempunyai pola meninggi pada daerah sekitar pusat semburan (Gambar 10.A). Pola tersebut kemungkinan merupakan indikasi bahwa terdispersi dari pusat semburan.

Kisaran harga Mn 3171095 ppm, rata-rata relatif rendah, akan tetapi terdapat nilai tinggi di beberapa lokasi. Pola sebaran Mn cenderung kurang teratur (Gambar 10.B). Nilai tinggi terdapat di dekat pusat semburan dan pada beberapa lokasi yang jauh dari pusat semburan. 
Harga rata-rata $\mathrm{Pb}$ pada endapan lumpur agak tinggi dibandingkan rata-rata pada batu lempung. Pola sebaran dengan nilai tinggi dijumpai jauh dari pusat semburan terutama pada daerah utara dan pola nilai rendah pada daerah sekitar pusat semburan menerus ke arah selatan (Gambar 10.C). Unsur Pb mempunyai sifat yang kurang mobile, pola sebaran dengan nilai tinggi justru jauh dari pusat semburan kemungkinan akibat adanya fluktuasi kandungan unsur pada lumpur yang keluar.

Nilai kandungan rata-rata $\mathrm{Sb}$ relatif agak tinggi dengan pembanding rata-rata pada batu lempung. Nilai tinggi $730 \mathrm{ppm}$ berada pada pusat semburan dan sekitarnya (Gambar 10.D). Pola meninggi di sekitar pusat semburan ke arah barat daya mengindikasikan bahwa terdispersi dari pusat semburan.

Kadar Se mempunyai rata-rata agak tinggi terutama pada daerah-daerah yang jauh dari pusat semburan. Kisaran nilai rendah $m$ :mpunyai sebaran di sekitar pusat semburan menerus ke arah selatan (Gambar 10.E). Pola tersebut mengindikasikan bahwa kandungan Se ada pengaruh dari keluarnya lumpur. Pola sebaran dengan nilai rendah pada daerah dekat semburan kemungkinan akibat fluktuasi dari kadar Se yang terbawa keluar bersama lumpur dari waktu ke waktu mempunyai nilai yang tidak konstan.

Kadar rata-rata $\mathrm{Zn}$ di bawah rata-rata pada batu lempung. Namun kisaran nilai yang agak tinggi $100-142$ ppm berada pada dekat pusat semburan menerus ke arah selatan (Gambar 10.F). Pola sebaran Zn mengindikasikan bahwa kemungkinan sumber dispersi dari pusat semburan.

\section{Analisis Multivariat}

Analisis unsur secara multivariat terutama untuk mengetahui kekerabatan unsur. Berdasarkan diagram dendogram (Gambar 7) diperoleh tiga kekerabatan unsur, yaitu antara $\mathrm{Ag}-\mathrm{Cd}-\mathrm{Pb}-\mathrm{Zn}-\mathrm{Sb}, \mathrm{Cu}-\mathrm{Mn}-\mathrm{Hg}$ dan $\mathrm{Au}-\mathrm{Se}-\mathrm{As}-\mathrm{Fe}$. Sedangkan berdasarkan analisis skor faktor (Tabel 2) diperoleh kekerabatan antara $\mathrm{Pb}-\mathrm{Zn}-\mathrm{Mn}-\mathrm{Ag}-\mathrm{Cd}, \mathrm{Cu}-\mathrm{Mn}-\mathrm{Hg}$ dan Ag-Sb.

Berdasarkan kedua metodologi tersebut terdapat konsistensi kekerabatan antara Cu-Mn-Hg. Sementara unsur yang juga selalu dalam satu kelompok kekerabatan, yaitu Ag$\mathrm{Sb}$ dan $\mathrm{Zn}-\mathrm{Cd}$-Ag. Kelompok kekerabatan skor faktor 1 antara $\mathrm{Pb}-\mathrm{Zn}-\mathrm{Mn}-\mathrm{Ag}-\mathrm{Cd}$ membentuk pola peninggian di daerah barat dan timur pusat semburan. Pola sebaran skor faktor 1 cenderung merupakan kelompok kekerabatan dengan logam dasar (Gambar 11.A). Sedangkan kelompok kekerabatan skor faktor 2 \& 3 cenderung merupakan gambaran zona epitermal atas (Gambar 11.B,C) membentuk pola peninggian di sekitar pusat semburan menerus ke selatan di sekitar Desa Jatianom dan Jatirejo. Pola sebaran skor faktor 2 \& 3 dengan kekerabatan kuat/tinggi mirip dengan pola sebaran skor faktor 1 dengan kekerabatan negatif/rendah.

Pola sebaran dan kekerabatan unsur tersebut mengindikasikan bahwa kandungan unsur yang keluar bersama semburan lumpur mempunyai kadar unsur yang tidak selalu sama selama kurun waktu terbentuknya endapan lumpur.

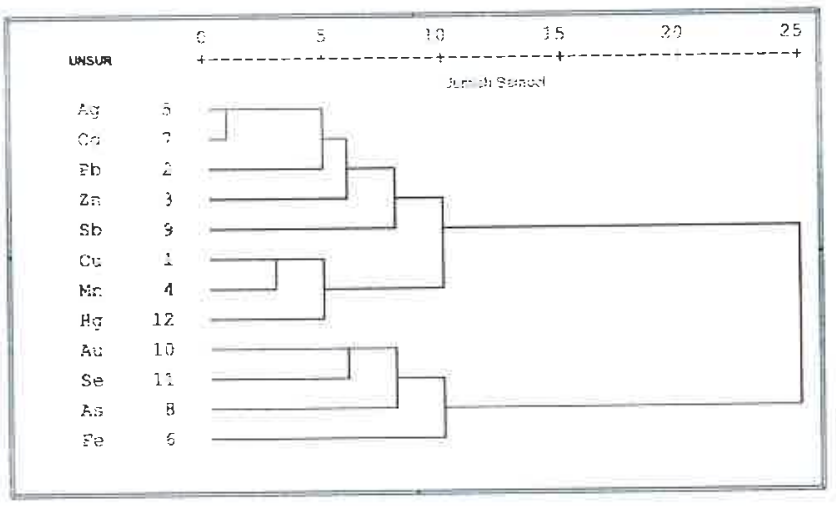

Gambar 7. Diagram dendogram

Tabel 2. Hasil analisis skor faktor

\begin{tabular}{|c|c|c|c|c|}
\hline \multirow{2}{*}{ Unsur } & \multicolumn{4}{|c|}{ Komponen } \\
\cline { 2 - 5 } & 1 & 2 & 3 & 4 \\
\hline $\mathrm{Cu}$ & 0.187 & $\mathbf{0 . 8 2 1}$ & 0.000 & -0.103 \\
\hline $\mathrm{Pb}$ & $\mathbf{0 . 6 8 6}$ & -0.101 & -0.096 & 0.352 \\
\hline $\mathrm{Zn}$ & $\mathbf{0 . 5 2 1}$ & 0.149 & 0.113 & -0.140 \\
\hline $\mathrm{Mn}$ & $\mathbf{0 . 6 5 8}$ & $\mathbf{0 . 5 3 3}$ & -0.117 & -0.038 \\
\hline $\mathrm{Ag}$ & $\mathbf{0 . 7 5 1}$ & 0.209 & $\mathbf{0 . 3 3 8}$ & 0.004 \\
\hline $\mathrm{Fe}$ & 0.129 & -0.169 & -0.108 & -0.695 \\
\hline $\mathrm{Cd}$ & $\mathbf{0 . 7 6 7}$ & 0.021 & 0.296 & 0.138 \\
\hline $\mathrm{As}$ & -0.641 & -0.042 & -0.056 & 0.171 \\
\hline $\mathrm{Sb}$ & 0.149 & 0.092 & $\mathbf{0 . 7 2 5}$ & -0.013 \\
\hline $\mathrm{Au}$ & 0.116 & -0.226 & -0.282 & 0.702 \\
\hline $\mathrm{Se}$ & -0.136 & -0.054 & -0.781 & 0.084 \\
\hline $\mathrm{Hg}$ & $\mathbf{0 . 0 2 2}$ & $\mathbf{0 . 7 6 7}$ & 0.228 & 0.106 \\
\hline
\end{tabular}

Pola sebaran dan kekerabatan unsur tersebut mengindikasikan bahwa kandungan unsur yang keluar bersama semburan lumpur mempunyai kadar unsur yang tidak selalu sama selama kurun waktu terbentuknya endapan lumpur.

\section{DISKUSI}

Semburan lumpur panas di Porong, Kabupaten Sidoarjo merupakan fenomena geologi yang cukup kompleks. Kegiatan yang semula terkait dengan eksplorasi Migas, namun akibat gagalnya pemboran dan menimbulkan bencana berupa semburan lumpur panas yang tidak terkendali memberikan dampak luas bagi masyarakat sekitarnya, bahkan telah menjadi masalah nasional. 
Fenomena geologi berupa semburan lumpur panas disamping sangat menonjol dari aspek kebencanaan, akan tetapi fenomena yang muncul perlu diungkap secara tuntas dan menyeluruh, sehingga kejadian yang sangat langka tersebut tidak semata-mata menjadi musibah yang memang harus segera ditanggulangi, akan tetapi juga menjadi lahan penyelidikan dan penelitian yang akan memperkaya khasanah kegeologian di tanah air.

Semburan lumpur dengan suhu yang cukup tinggi yaitu sekitar $1000 \mathrm{C}$ telah menimbulkan dugaan atau hipotesis akan adanya sistim geotermal hasil proses magmatik yang ikut mempengaruhi suhu lumpur yang keluar. Keterlibatan sistem geotermal tentu saja akan memberikan pengaruh tidak hanya pada efek naiknya suhu, akan tetapi fluida yang dihasilkan mempunyai sifat melarutkan unsur-unsur logam, sehingga apabila ikut terbawa keluar bersama lumpur akan mempengaruhi kandungan unsur logam pada endapan lumpur.

Hasil penyelidikan geokimia endapan lumpur Sidoarjo dengan melakukan analisis kimia kandungan unsur logam pada lumpur menunjukkan pola sebaran beberapa unsur logam yang relatif beragam. Pola sebaran beberapa unsur mempunyai nilai yang tinggi pada daerah jauh dari pusat semburan dan cenderung redah pada sekitar pusat semburan. Akan tetapi beberapa unsur mempunyai pola yang jelas menunjukkan peninggian pada arah mendekati pusat semburan.

Sampel lumpur yang terambil saat penyelidikan mempunyai umur yang relatif berbeda. Lumpur pada lokasi jauh dari pusat semburan sebagian sudah mengering, merupakan endapan awal terjadinya semburan lumpur panas. Sementara pada sekitar pusat semburan saat pengambilan sampel masih terus terjadi penambahan lumpur dan dialirkan ke arah selatan menuju Sungai Porong. Pola sebaran unsur tertentu yang menunjukkan nilai kandungan unsur dengan peninggian dan nilai rendah pada daerah dekat pusat semburan maupun jauh dari pusat semburan dapat diduga bahwa kandungan unsur lumpur dari waktu ke waktu tidak konstan akan tetapi mengalami fluktuasi. Pola sebaran beberapa unsur yang meninggi ke arah pusat semburan mengindikasikan bahwa terdispersi dari pusat semburan lumpur.

Peninggian nilai beberapa unsur dibandingkan dengan rata-rata yang umum terdapat pada batu lempung memberikan kemungkinan bahwa ada pengaruh larutan hidrotermal dari aktivitas magmatik pada zona kedalaman yang mempengaruhi kandungan semburan lumpur. Proses peninggian beberapa kandungan unsur pada lumpur dapat terjadi saat masih insitu berada pada kedalaman semula, atau akibat setelah tersemburkan keluar ada imbuhan kandungan unsur yang terakumulasi dan terdispersi kemudian. Keterdapatan peninggian sebagian unsur logam dasar yang merupakan penciri suhu tinggi (Gambar 7) dimungkinkan sebagai akibat kecepatan keluarnya fluida yang relatif tinggi sehingga membawa serta unsur-unsur yang umumnya terbentuk pada zona dalam dan suhu tinggi.

Peninggian kandungan beberapa jenis unsur yang umum terlarut pada fluida geotermal memperkuat dugaan akan adanya aktivitas geotermal yang ikut mempengaruhi keterjadian lumpur panas. Unsur yang terbawa fluida geotermal yang keluar bersama semburan lumpur akan berpotensi terakumulasi pada daerah aliran lumpur. Oleh karena itu pemantauan terhadap perubahan kandungan unsur tersebut secara periodik dalam kurun waktu tertentu sangat diperlukan untuk mendapatkan gambaran pola sebaran secara lebih lengkap.

\section{KESIMPULAN}

Berdasarkan data dan pembahasan di atas dapat ditarik kesimpulan bahwa pada proses keluamya Lumpur Sidoarjo terdapat sistim geotermal yang ikut mempengaruhi. Hal ini tercermin dari pola sebaran unsur yang umum dijumpai pada lingkungan sistim geotermal khusunya pada suhu epitermal yang memberikan pola peninggian dari pusat semburan.

Pola sebaran kandungan unsur menunjukkan adanya fluktuasi kadar unsur dari waktu ke waktu, serta memberikan gambaran pada beberapa unsur terdispersi dari pusat semburan.

Kandungan penyusun Lumpur Sioarjo dapat berasal dari sekitar lubang Bor Banjar Panji I (BJP-I) yang merupakan zona cekungan hidrokarbon, dari zona resapan air daerah sekitarnya, serta dari sistim geotermal.

\section{UCAPANTERIMAKASIH}

Terimakasih disampaikan kepada Kepala Pusat Sumber Daya Geologi yang telah memberikan dorongan untuk menyusun tulisan ini, rekan-rekan di Kelompok Program Penelitian Konservasi atas bantuannya, serta Ir. Bambang Pardiarto dan Ir. Teuku Ishlah selaku editor atas saran dan koreksinya. 


\section{ACUAN}

Gunradi, R, dan Sukandar, M., 2007. Penelitian Endapan Lumpur di Daerah Porong, Kabupaten Sidoarjo, Provinsi Jawa Timur. Pusat Sumber Daya Geologi, Bandung

Panteleyev, A., 1990. A Canadian Cordilleran Model for Epithermal Gold-Silver Deposits. Di dalam : Roberts, R.G. dan Sheahan, P.A. Ore Deposit Models. Geological Association of Canada, Ontario

Rovicky, 2007. Masih Soal Hipotesa Kelahiran Lusi. http://rovicky.wordpress.com/2007/03/16/masih-soal-hipotesa-kelahiranlusi/

Santosa, S dan Suwarti, T., 1992. Geologi Lembar Malang, Jawa. Pusat Penelitian dan Pengembangan Geologi, Bandung

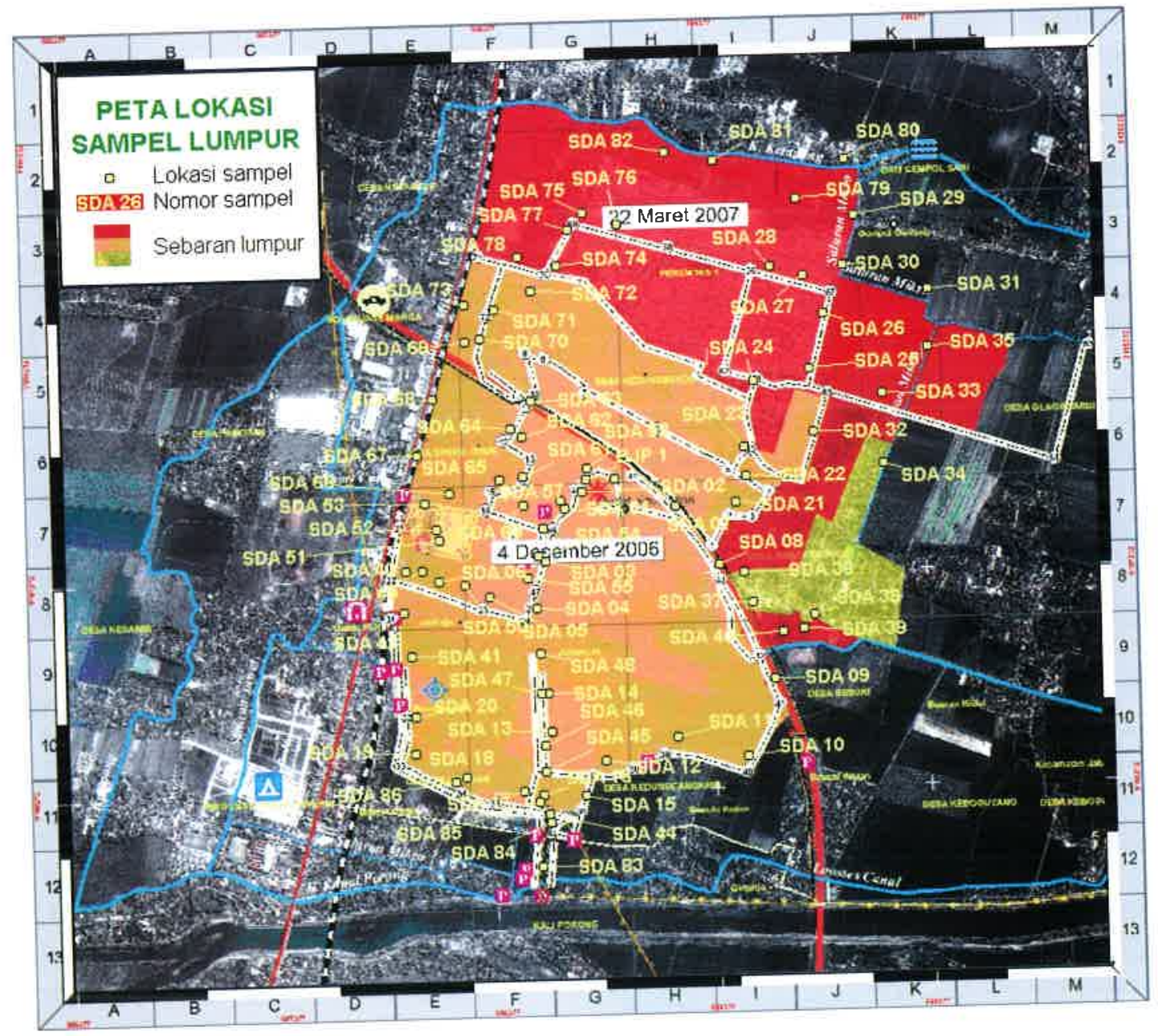

Gambar 8. Peta lokasi sampel lumpur (sumber peta dasar dari Balitbang-PU) 


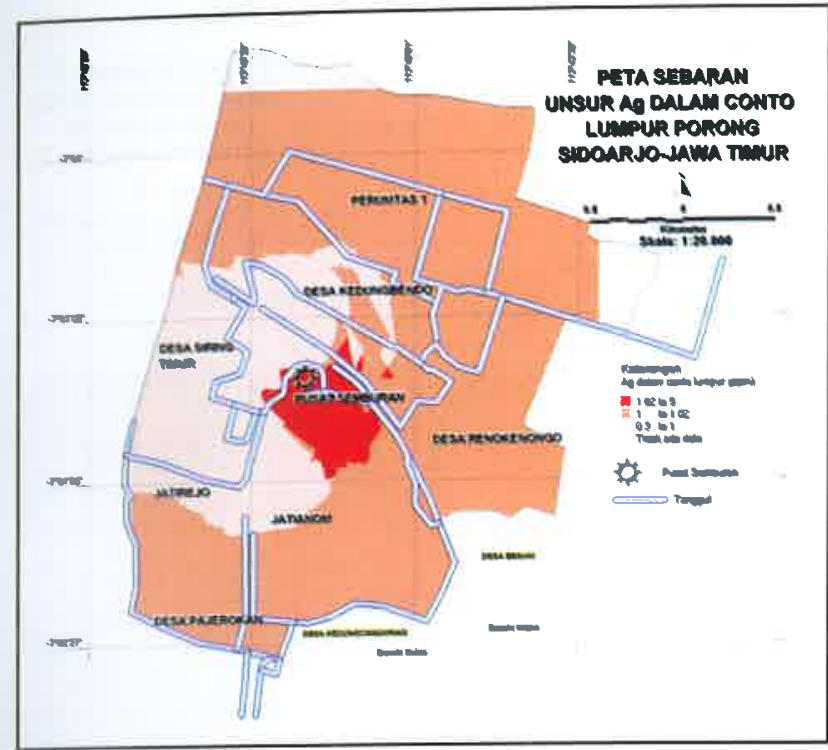

A

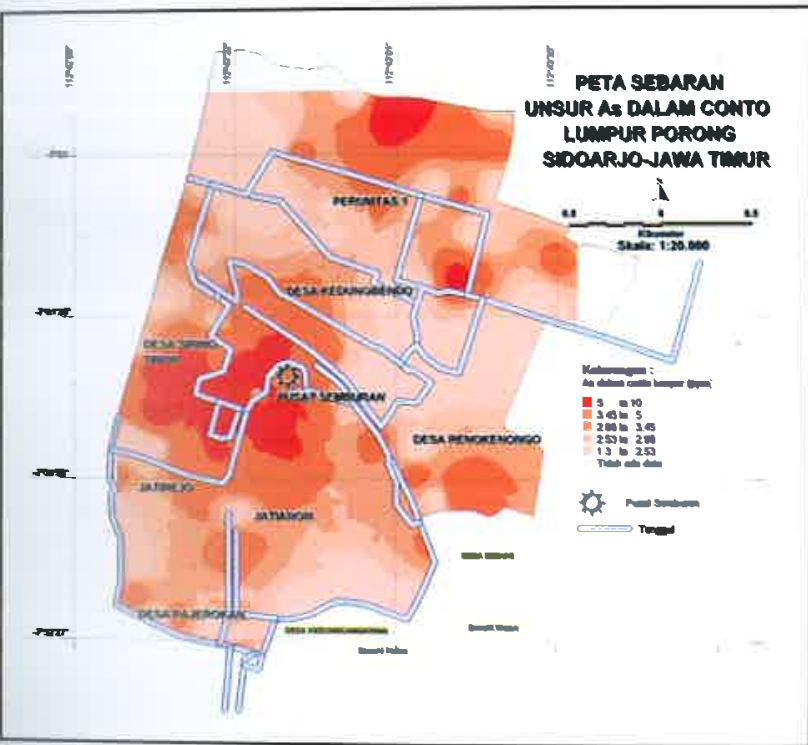

B

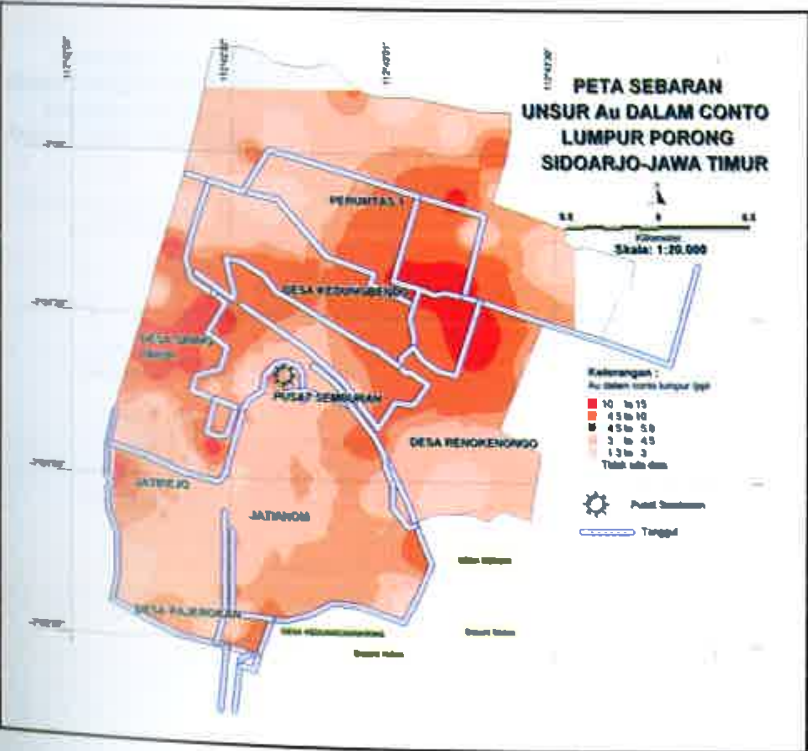

C

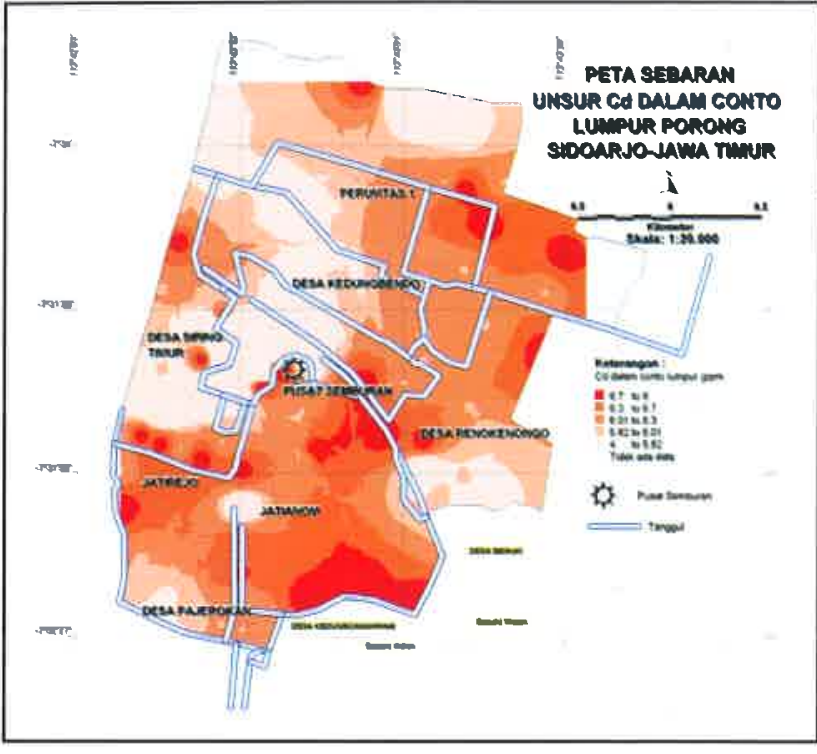

D

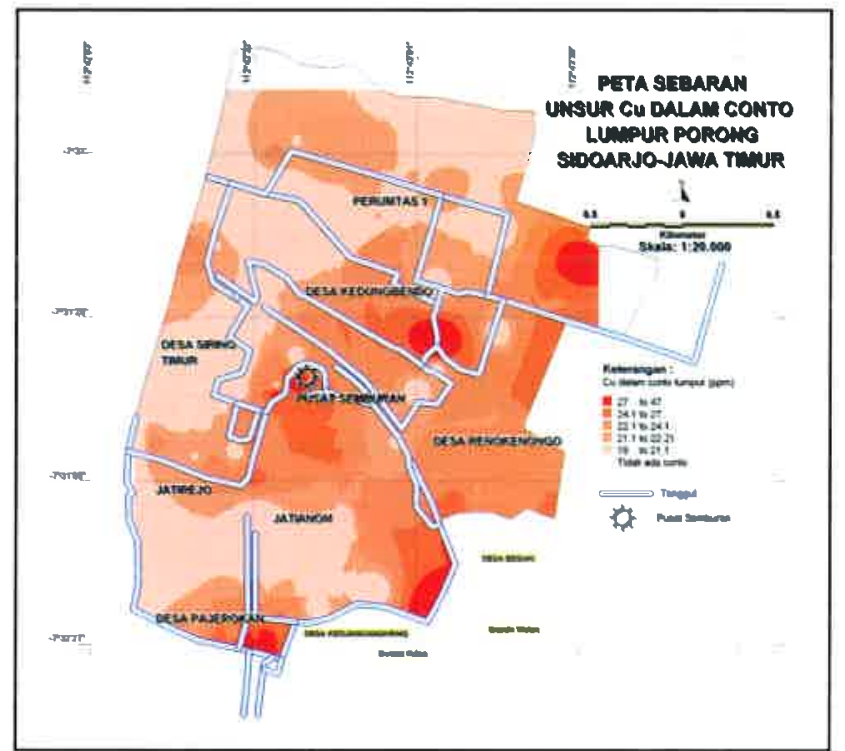

$E$

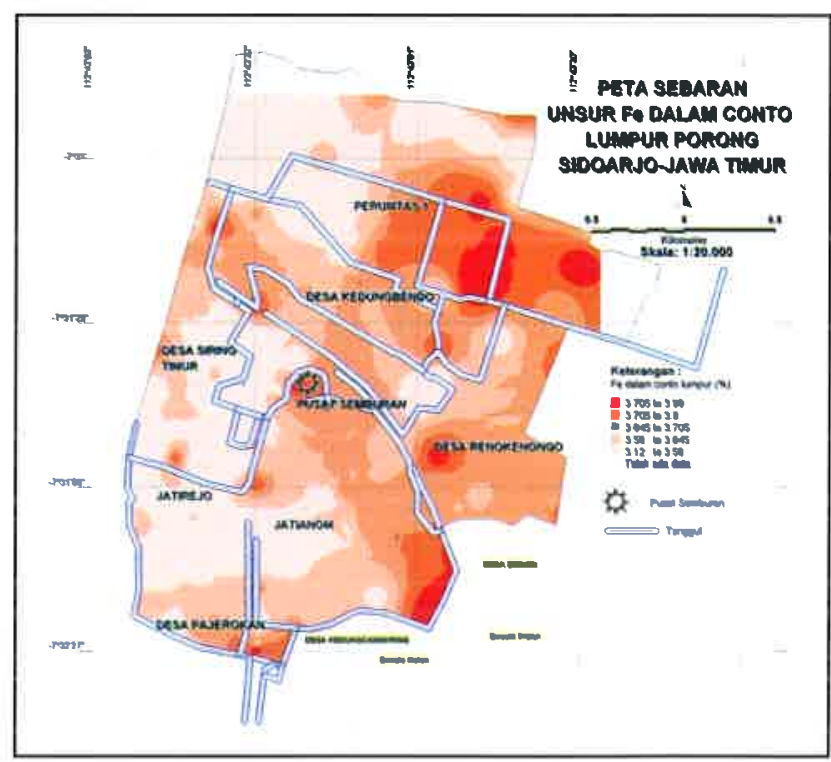

F

Gambar 9. Peta sebaran unsur pada endapan Lumpur Sidoarjo 

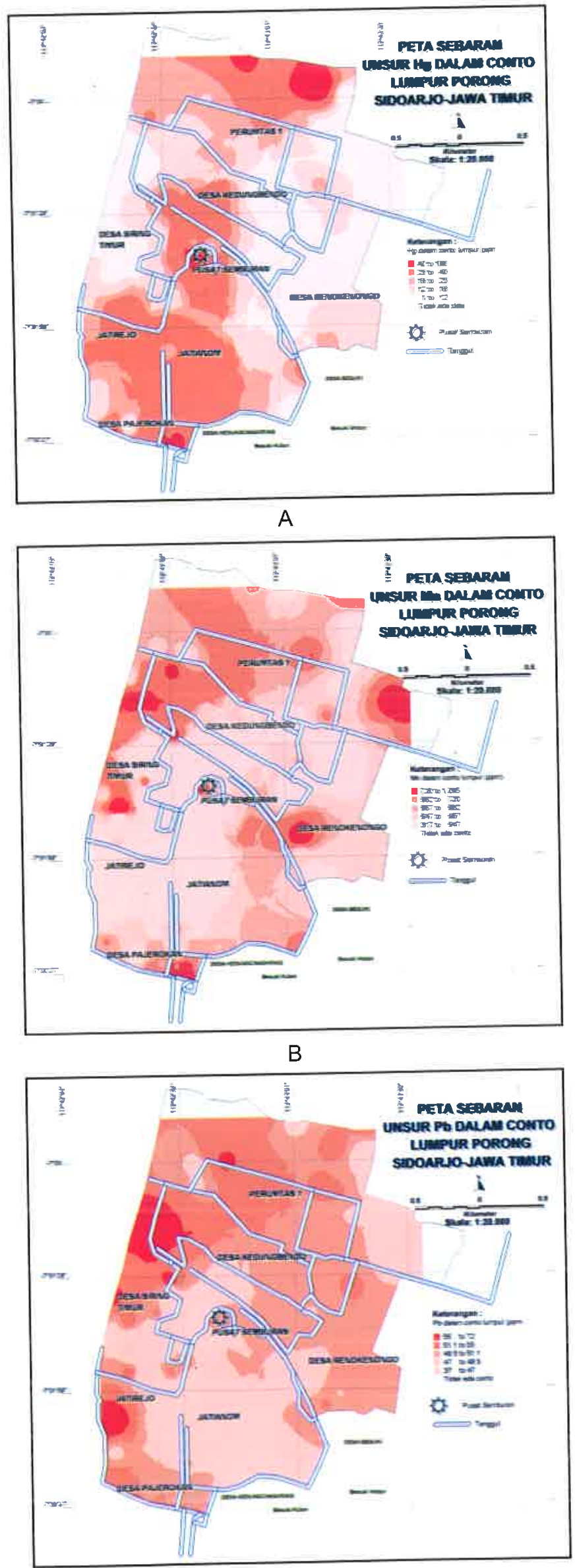

C

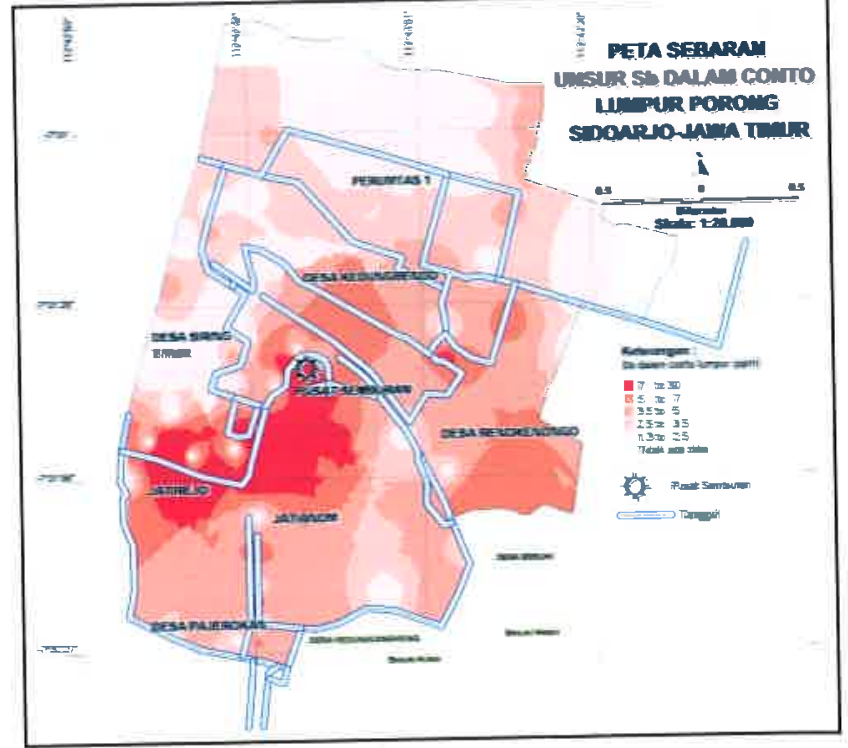

D

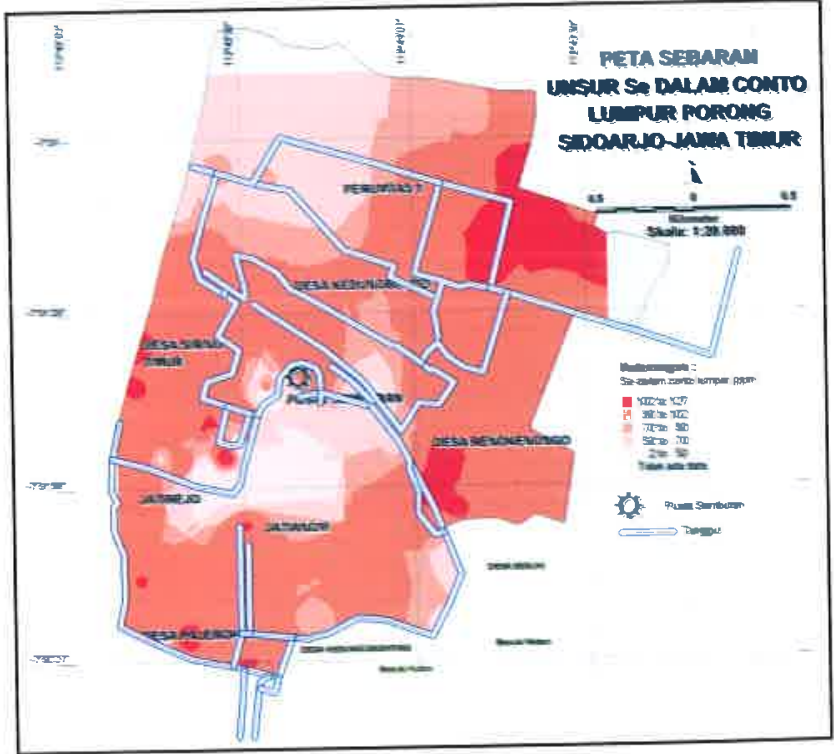

$E$

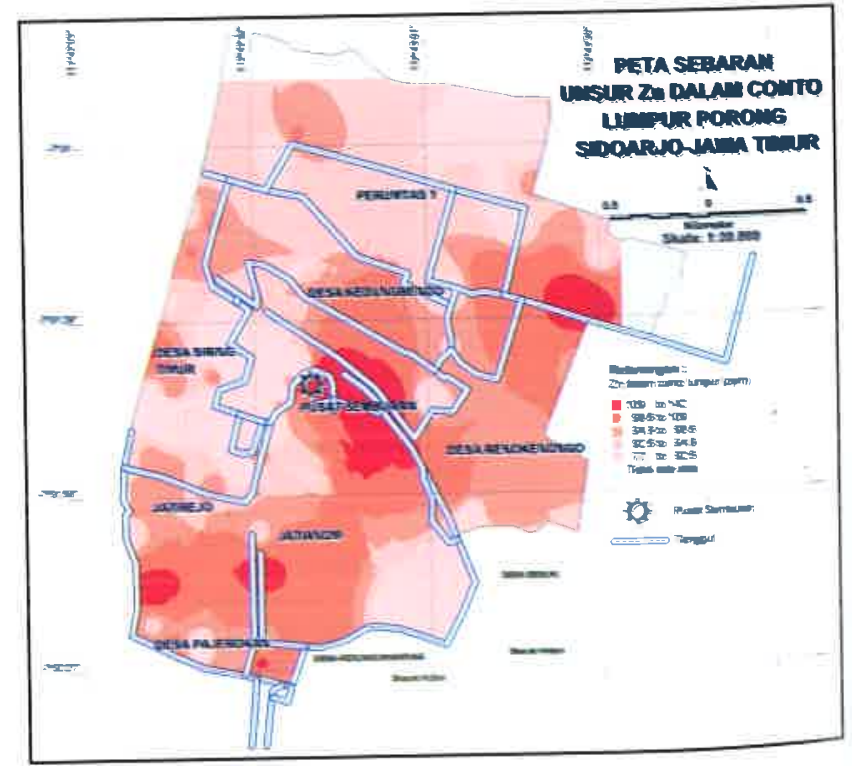

F

Gambar 9. Peta sebaran unsur pada endapan Lumpur Sidoarjo 


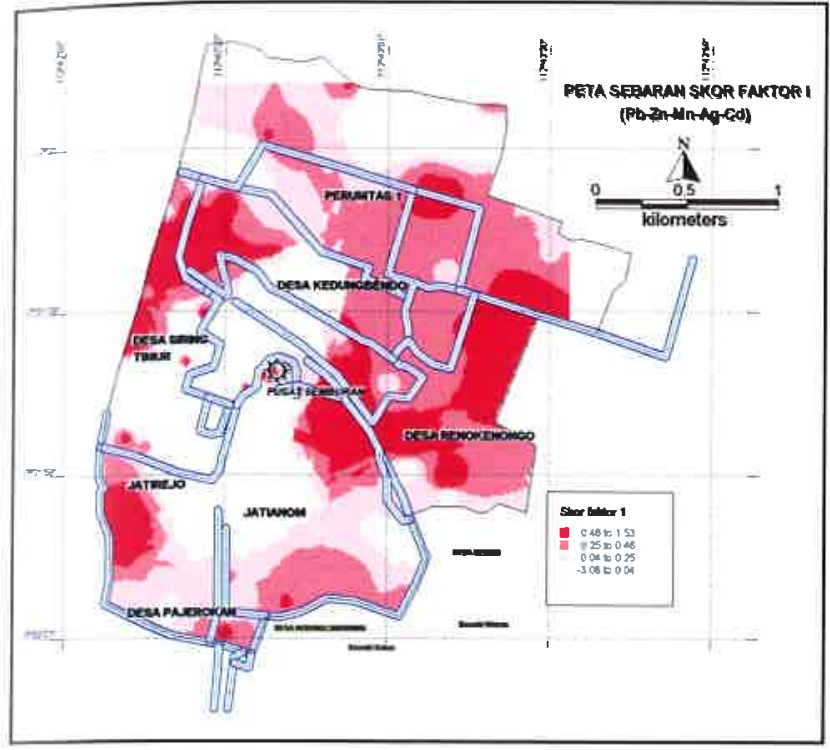

A

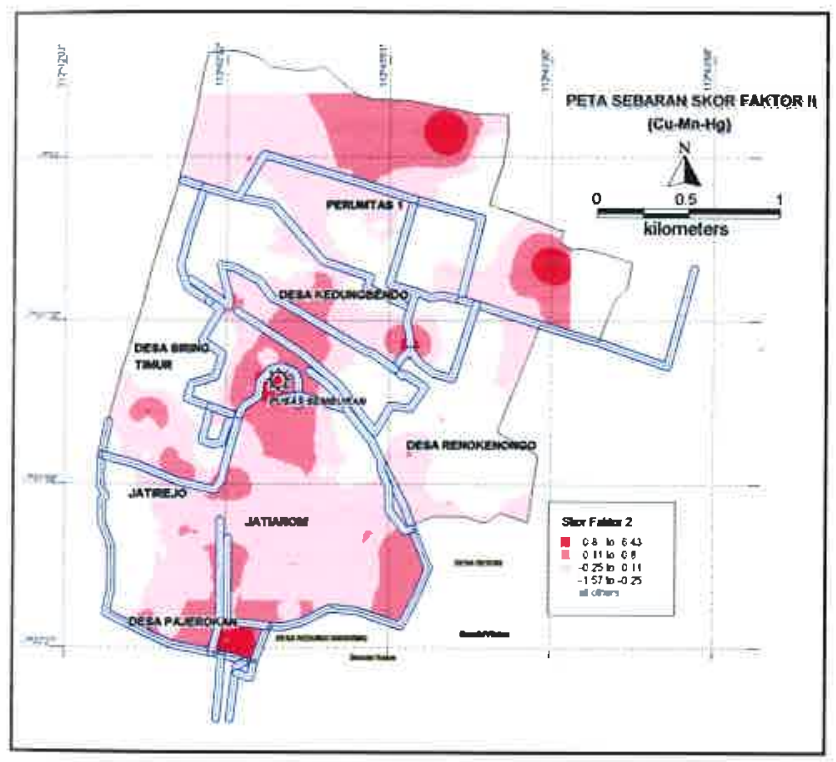

B

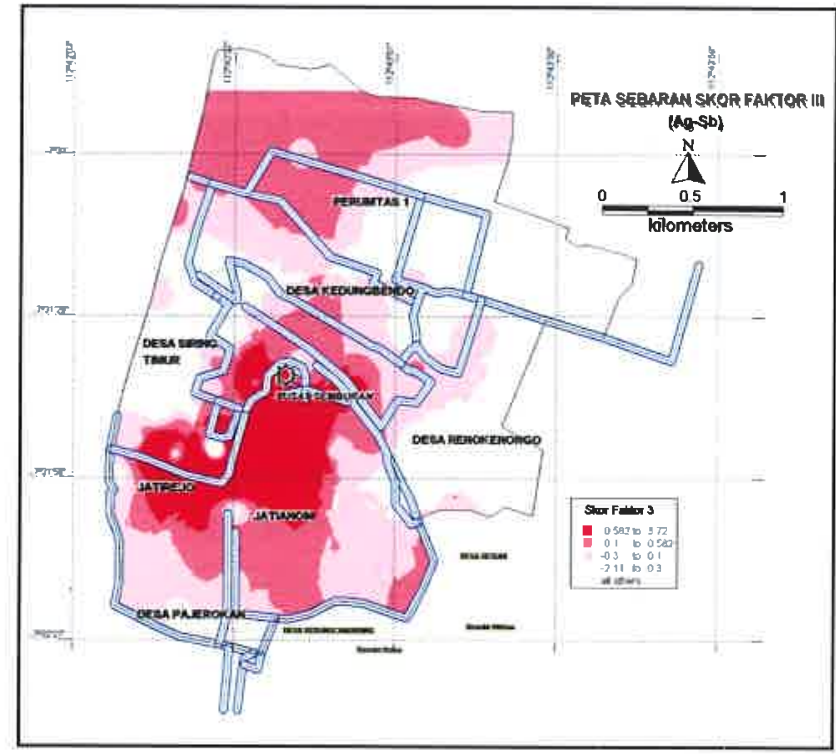

C

Gambar 11. Peta sebaran skor faktor kekerabatan unsur A. Pb-Zn-Mn-Ag-Cd, B. Cu-Mn-Hg, C. Ag-Sb 